\title{
39. TRACE FOSSILS IN LEG 42A CORES
}

\author{
A. A. Ekdale, Department of Geology and Geophysics, University of Utah, Salt Lake City, Utah
}

\begin{abstract}
Trace fossils abound in pelagic carbonates cored on Leg 42A, particularly at Sites $371,372,374,375,376$, and 378. The ichnogenera Chondrites, Planolites, and Zoophycos comprise a typically deep-sea trace fossil assemblage; all three are abundant in pre-Messinian as well as post-Messinian deposits. This suggests that water depths of hundreds or, more likely, thousands of meters existed in the Mediterranean Sea before and after the period of massive evaporite deposition in the upper Miocene.
\end{abstract}

\section{INTRODUCTION}

Biogenic sedimentary structures are significant evidences of the presence and life habits of benthic creatures, especially when they become preserved in ancient sediment as trace fossils and reflect the activities of ancient bottom-dwelling organisms. Such indirect paleontologic evidence (i.e., trace fossils) in deepsea deposits is extremely important to paleoecologists, because the large majority of benthic macro-organisms living at abyssal and hadal depths (greater than 2000 $\mathrm{m})$ rarely enter the fossil record. Usually these creatures are either (1) soft-bodied and geologically unpreservable (e.g., polychaetes, echiurids, hydrozoans, actinarians); (2) sheathed in thin, easily decomposable, chitinous carapaces (e.g., arthropods); (3) supported by loosely jointed siliceous or calcareous spicules or plates that disaggregate rapidly after death (e.g., hyalosponges, holothuroids, ophiuroids, stelleroids); or (4) housed in calcareous shells that cannot withstand the dissolution of calcium carbonate in seawater below the lysocline (e.g., molluscs, brachiopods).

That the modern deep sea contains an overwhelming abundance and diversity of benthic life, particularly benthic macroinvertebrate life, has been demonstrated by Sanders and Hessler (1969), Zenkevitch (1970), Heezen and Hollister (1971), Menzies et al. (1973), and many others. Unfortunately for the geologist, very few of these creatures make it into the fossil record. Thus trace fossils, as they are preserved in ancient deep-sea sediments and especially in the DSDP cores, may be our only significant source of information about the paleoecology and geologic history of ancient abyssal and hadal macroinvertebrates (Ekdale, 1974; Crimes, 1975).

Trace fossils abound in deep-sea cores of Neogeneage sediment (e.g., see Bramlette and Bradley, 1940; Arrhenius, 1952; Ericson et al., 1961; Donahue, 1971) as well as in DSDP cores of much older sediment (Ekdale, 1974; Chamberlain, 1975). Trace fossil assemblages have been described from selected DSDP sites of Leg 15 in the Caribbean Sea (Warme et al.,
1973), Leg 18 in the northeastern Pacific (Piper and Schrader, 1973) and Leg 21 in the southwestern Pacific (van der Lingen, 1973).

Because strata drilled by Glomar Challenger commonly are soft and sticky to depths of several hundred meters below the sediment surface, trace fossils or other sedimentary structures may be smeared and destroyed during the drilling operation. This was the case with virtually all the samples obtained in the Mediterranean Sea on Leg 13 (see core photographs in Ryan, Hsü, et al., 1973). Consequently, no trace fossils have been described in cores from that leg. Cores from Leg $42 \mathrm{~A}$, however, contain hundreds of meters of intensely bioturbated sediments that are suitable for trace fossil study. These cores, principally from Sites 371, 372, $374,375,376$, and 378 in the Mediterranean Sea, form the basis of this report.

\section{TRACE FOSSILS}

Although the International Code of Zoological Nomenclature does not recognize trace fossils as valid taxa, it has been customary for paleontologists to assign informal generic and specific names (ichnogenera and ichnospecies) to trace fossils in the literature (see Häntzschel, 1962, 1965, 1975). Deep-sea cores often do not contain enough of a burrow for the total geometry of the structure to be examined, so it is usually unadvisable to designate such specimens with an ichnospecies name. Instead, a particular ichnogenus may be subdivided descriptively according to its appearance and/or size in cross-section in the core.

\section{Ichnogenus CHONDRITES Sternberg, 1833}

Chondrites ichnosp.

(Plate 1, Figures 1, 2, 4, 5)

Description: Chondrites is a simple root-like system of regularly branching feeding tunnels of uniform diameter which never anastomose nor cut across one another. Branching typically is in the form of side branches angling off a previous or main tunnel at $30^{\circ}$ to $40^{\circ}$ rather than bifurcation of tunnels at $\mathrm{Y}$-shaped junctions. (For further description, see Simpson, 1957; Osgood, 1970; Häntzschel, 1975.)

In DSDP cores Chondrites commonly appears as an array of tiny circular or elongate dots where the vertical slice through the core truncates the numerous branching tunnels. In some cores longitudinal sections through individual tunnels and broken portions of branches are exposed (e.g., see Warme et al., 1973, pl. 1).

Remarks: Chondrites occurs in great profusion in lower Miocene to Pleistocene sediments in Leg $42 \mathrm{~A}$ cores from both the eastern and 
western portions of the Mediterranean (see Table 1). The burrows are most evident immediately below interfaces between dark and light colored sediment, indicating that material from above was piped down into underlying sediment of a contrasting color in an open burrow system. The tunnel diameters in Chondrites specimens in the Leg $42 \mathrm{~A}$ cores range from less than $0.5 \mathrm{~mm}$ to approximately 1.5 $\mathrm{mm}$.

\section{Ichnogenus PLANOLITES Nicholson, 1873}

Planolites ichnosp.

(Plate 1, Figures 3, 6, 7)

Description: Planolites is a smooth-walled, cylindrical to subcylindrical, sediment-filled tunnel. It is usually straight or slightly sinuous, and the orientation is dominantly horizontal or subhorizontal. Internal structure and surface sculpture of the burrow generally are absent, although internal backfilling may be observed in some specimens. (For further description, see Alpert, 1975; Häntzschel, 1975.)

In split-core sections of DSDP cores Planolites most often appears as a solid-colored circle or ellipse, ranging in diameter from 0.5 to $3.0 \mathrm{~cm}$.

Remarks: Planolites is ubiquitous in deep-sea sediments. It occurs in lower Miocene through upper Pliocene deposits in Leg $42 \mathrm{~A}$ cores (sec Table 1). Commonly Planolites occurs in juxtaposition with Chondrites, usually with the latter cutting across the former, indicating that Planolites was produced earlier and presumably at a shallower depth in the sediment than Chondrites. In some cases it appears that Planolites was preferentially reburrowed by Chondrites, perhaps because of a higher concentration of organic matter in the former burrow than in the surrounding sediment (see Plate 1, Figure 5)

Ichnogenus ZOOPHYCOS Massalongo, 1855

Zoophycos ichnosp. (Plate 2)

Description: Although the ichnogenus encompasses a wide variety of forms, Zoophycos is basically a circular or lobate sheet-like spreite, either flat, curved, inclined, or wound in screw fashion around a central vertical axis. The spreite is a horizontal or subhorizontal web of closely juxtaposed parallel burrow tunnels. Each tunnel in the burrow system presumably represents the path of the organism (or perhaps just the path of its feeding apparatus) during a single probing of the sediment. Successive probings side-by-side in the same plane produce a horizontal spreite resembling the vertical spreite of Technichnus and similar ichnogenera. (For further description, see Taylor, 1967; Lewis, 1970; Simpson, 1970; Häntzschel, 1975.)

In DSDP cores Zoophycos is seen as a horizontal or subhorizontal line of imbricate, lunate, concave-out backfill structures. These apparently represent a cross-section through the tight series of abandoned tunnels where the slice through the core has cut vertically across the spreite.

Remarks: Zoophycos is perhaps the most distinctive trace fossil in Leg $42 \mathrm{~A}$ cores. It occurs in lower Miocene to Pleistocene sediments in both the eastern and western portions of the Mediterranean (see Table 1), although it is generally not as abundant in the cores as Chondrites and Planolites. Although it may be seen in direct association with the other two burrow types, Zoophycos usually occurs by itself and of ten in great profusion (see Plate 2, Figures 1-3).

\section{DISCUSSION}

The paleobathymetric significance of trace fossils was first studied in detail by Seilacher $(1963,1967)$, who outlined a sequence of six bathymetric facies characterized by particular ichnogenera: Scoyenia facies (trace fossils in nonmarine redbeds), Skolithos facies (in rapidly deposited intertidal-shallow subtidal sediments), Glossifungites (= Rhizocorallium) facies (in erosion surfaces in the intertidal-shallow subtidal zone), Cruziana facies (in subtidal sediments deposited above effective wave base), Zoophycos facies (in outer shelf or slope sediments deposited at intermediate depths), and Nereites facies (in bathyl to abyssal pelagic sediments and turbidites). Seilacher's bathymetric scheme has been applied with reasonable success to various Paleozoic basins by Rodriquez and Guttschick (1970), Chamberlain (1971), Chamberlain and Clark (1973), and others, but its application to post-Paleozoic deposits is limited. Indeed, the trace fossils Scoyenia, Skolithos, and Cruziana themselves are virtually absent from sediments younger than Paleozoic.

Water depth governs trace fossil distribution only to the extent that it governs the range of the trace-making organisms. Sediment grain size, depositional rate, nutrient supply, and other factors also are important. In the deep sea the water depth, grain size, and depositional rate apparently do not vary enough to markedly affect trace fossil distribution; nutrient supply and available food resources to benthic organisms may be much more significant. Evenso, the typical assemblage of trace fossils in Mesozoic and Cenozoic deepsea deposits is monotonous and diagnostic only of a general deep-water pelagic facies.

The trace fossil assemblage in Leg $42 \mathrm{~A}$ cores, characterized by Chondrites, Planolites, and Zoophycos, is typical of that found in cores of deep-sea sediments from all over the world (Donahue, 1971; Piper and Schrader, 1973; van der Lingen, 1973; Warme et al., 1973; Ekdale, 1974; Chamberlain, 1975). Although Seilacher (1964) and Häntzschel (1975) believe that Chondrites and Planolites hold little value as bathymetric indicators, it is a fact that few post-Paleozoic occurrences of these ichnogenera have been reported in anything but deep-water sediment. For example, finegrained, basinal limestones in the Lias of Morocco's High Atlas mountain chain contain abundant Chondrites and Planolites identical to those found in deepsea cores. Osgood and Szumuc (1972) have stated that Zoophycos also is an unreliable bathymetric indicator, because it is widespread in both shallow-water and deep-water Paleozoic deposits. However, post-Paleozoic occurrences of Zoophycos are rare in anything other than deep water sediments (e.g., see Seilacher, 1967; Taylor, 1967; Frey, 1970, 1972; Donahue, 1971; Kern and Warme, 1974). It appears safe to assume that the Chondrites-Planolites-Zoophycos association is a typically deep-sea trace fossil assemblage (see also Kennedy, 1975). Although Teichichnus also may be a common member of the assemblage (Warme et al., 1973; Ekdale, 1974), it is rare in the Leg 42A cores.

Deep-water grazing trails of Seilacher's Nereites facies have been photographed on the modern deepsea floor (Bourne and Heezen, 1965; Ewing and Davis, 1967; Heezen and Hollister, 1971; Hollister et al., 1975 ), but these surficial structures are rarely preserved in most deep-sea sediment due to slow, continuous deposition accompanied by intense reworking of the sediment by infaunal organisms. Rapid burial beneath periodic turbidity current deposits will allow preservation of some surficial traces on bedding planes. However, where sedimentation is continuous and bedding planes are absent, as in most of the sediments 
TABLE 1

Partial List of Typical Trace Fossil Occurrences in Leg 42A Cores

\begin{tabular}{lllll}
\hline $\begin{array}{c}\text { Core- } \\
\text { Section }\end{array}$ & Age & Chondrites & Planolites & Zoophycos \\
\hline
\end{tabular}

Site 371

3-1 Upper Pliocene

3-2 Upper Pliocene

3-4 Upper Pliocene

3-5 Upper Pliocene

3-6 Upper Pliocene

4-2 Upper Pliocene

4-3 Upper Pliocene

4-4 Upper Pliocene

4-5 Upper Pliocene

4-6 Upper Pliocene

5-0 Upper Pliocene

5-1 Upper Pliocene

5-2 Upper Pliocene

5-3 Upper Pliocene

5-4 Upper Pliocene

5-5 Upper Pliocene

5-6 Upper Pliocene

Site $\mathbf{3 7 2}$

12-4 Middle Miocene

13-3 Middle Miocene

14-1 Middle Miocene

15-1 Middle Miocene

15-2 Middle Miocene

15-5 Middle Miocene

16-2 Middle Miocene

16-4 Middle Miocene

16-6 Middle Miocene

17-2 Middle Miocene

17-4 Middle Miocene

19-4 Middle Miocene

19-5 Middle Miocene

19-6 Middle Miocene

20-1 Middle Miocene

20-2 Middle Miocene

20-4 Middle Miocene

20-5 Middle Miocene

20-6 Middle Miocene

21-2 Middle Miocene

21-3 Middle Miocene

21-4 Middle Miocene

21-5 Middle Miocene

21-6 Middle Miocene

22-1 Middle Miocene

22-2 Middle Miocene

22-3 Middle Miocene

23-2 Middle Miocene

23-3 Middle Miocene

23-6 Middle Miocene

24-3 Middle Miocene

24-4 Middle Miocene

24-5 Middle Miocene

25-5 Middle Miocene

26-1 Middle Miocene

26-2 Middle Miocene

26-3 Middle Miocene

26-4 Middle Miocene

27-2 Middle Miocene

27-4 Middle Miocene

27-5 Middle Miocene

28-1 Middle Miocene

28-2 Middle Miocene

28-3 Middle Miocene

28-4 Middle Miocene

28-5 Middle Miocene

28-6 Middle Miocene

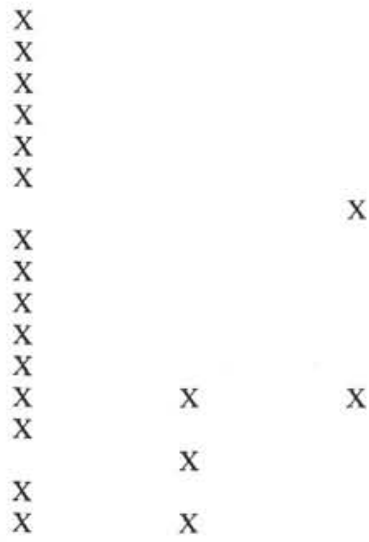

X

$\mathrm{X}$

$\mathrm{X}$

$\mathrm{X}$

$\mathrm{x}$

$\mathrm{X}$

$\mathrm{X}$

$\mathrm{X}$

$\mathrm{X}$

$\mathrm{X}$

$\mathrm{X}$

$\mathrm{X}$
5-2 Upper Pliocene

5-3 Upper Pliocene

5-4 Upper Pliocene

5-5 Upper Pliocene

7-0 Upper Pliocene

7-1 Upper Pliocene

7-2 Upper Pliocene

7-4 Upper Pliocene

7-5 Upper Pliocene

8-3 Upper Pliocene

9-1 Lower Pliocene

9-3 Lower Pliocene

9-4 Lower Pliocene

TABLE 1 - Continued

\begin{tabular}{|c|c|c|c|c|}
\hline $\begin{array}{l}\text { Core- } \\
\text { Section }\end{array}$ & Age & Chondrites & Planolites & Zoophycos \\
\hline $29-1$ & Middle Miocene & & $\mathrm{X}$ & \\
\hline $29-2$ & Middle Miocene & & & $\mathrm{X}$ \\
\hline $29-3$ & Middle Miocene & & $\mathrm{X}$ & \\
\hline $29-4$ & Middle Miocene & & & $\mathrm{X}$ \\
\hline $30-3$ & Middle Miocene & & $\mathrm{X}$ & $\mathrm{X}$ \\
\hline $30-5$ & Middle Miocene & & $\mathrm{X}$ & \\
\hline $31-1$ & Middle Miocene & $\mathrm{X}$ & $\mathrm{X}$ & $\mathrm{X}$ \\
\hline $31-2$ & Middle Miocene & & $\mathrm{X}$ & \\
\hline $31-4$ & Lower Miocene & $\mathrm{X}$ & $\mathrm{X}$ & $\mathrm{X}$ \\
\hline $31-6$ & Lower Miocene & & $\mathrm{X}$ & $\mathrm{X}$ \\
\hline $32-0$ & Lower Miocene & $\mathrm{X}$ & & \\
\hline $32-1$ & Lower Miocene & & & $\mathrm{X}$ \\
\hline $32-2$ & Lower Miocene & $\mathrm{X}$ & $\mathrm{X}$ & $\mathrm{X}$ \\
\hline $32-3$ & Lower Miocene & $\mathrm{X}$ & $\mathrm{X}$ & $\mathrm{X}$ \\
\hline $32-6$ & Lower Miocene & & $\mathrm{X}$ & \\
\hline $33-1$ & Lower Miocene & $\mathrm{X}$ & $\mathrm{X}$ & \\
\hline $33-2$ & Lower Miocene & & $\mathrm{X}$ & \\
\hline $33-3$ & Lower Miocene & $\mathrm{X}$ & $\mathrm{X}$ & \\
\hline $34-2$ & Lower Miocene & & $\mathrm{X}$ & \\
\hline $34-3$ & Lower Miocene & $\mathrm{X}$ & $\mathrm{X}$ & $x$ \\
\hline $34-5$ & Lower Miocene & & $\mathrm{X}$ & \\
\hline $35-3$ & Lower Miocene & & $\mathrm{X}$ & \\
\hline $37-2$ & Lower Miocene & & & $\mathrm{X}$ \\
\hline $42-1$ & Lower Miocene & & $\mathrm{X}$ & \\
\hline $42-3$ & Lower Miocene & & $X$ & \\
\hline 44-4 & Lower Miocene & & $\mathrm{X}$ & \\
\hline $44-5$ & Lower Miocene & & $\mathrm{X}$ & \\
\hline $45-1$ & Lower Miocene & & $\mathrm{X}$ & \\
\hline
\end{tabular}

$\mathrm{X}$

$\mathrm{x}$

X

$\mathrm{X}$

$\mathrm{X}$

$\mathrm{X}$

$\mathrm{X}$

$\mathrm{X}$

$\mathrm{x}$

$\mathrm{X}$

X

$\mathrm{X}$
$\mathrm{X}$

$\mathrm{X}$
$\mathrm{X}$
$\mathrm{X}$

Site 375

4-1 Upper Miocene

4-2 Upper Miocene

4-3 Upper Miocene

4-4 Upper Miocene

4-5 Upper Miocene

5-5 Upper Miocene

5-6 Upper Miocene

6-4 Upper Miocene

7-3 Upper Miocene

8-0 Middle Miocene

8-1 Middle Miocene

8-2 Middle Miocene

8-3 Middle Miocene

8-4 Middle Miocene

8-5 Middle Miocene

8-6 Middle Miocene

9-2 Middle Miocene

9-4 Middle Miocene

$\mathrm{X}$

$\begin{array}{ll}\mathrm{X} & \mathrm{X} \\ \mathrm{X} & \mathrm{X} \\ \mathrm{X}\end{array}$

Site 376

6-4 Quaternary

7-3 Upper Miocene

$\begin{array}{lll}\mathrm{X} & \\ \mathrm{X} & \mathrm{X} & \\ \mathrm{X} & & \mathrm{X} \\ \mathrm{X} & \mathrm{X} \\ \mathrm{X} & \mathrm{X} & \\ \mathrm{X} & \mathrm{X} & \\ & \mathrm{X} & \\ & \mathrm{X} & \mathrm{X} \\ \mathrm{X} & \mathrm{X} & \mathrm{X} \\ \mathrm{X} & \mathrm{X} & \mathrm{X} \\ \mathrm{X} & \mathrm{X} & \\ \mathrm{X} & \mathrm{X} & \mathrm{X} \\ & \mathrm{X} & \\ & & \mathrm{X} \\ & & \mathrm{X}\end{array}$


TABLE 1 - Continued

\begin{tabular}{rcccc}
\hline $\begin{array}{c}\text { Core- } \\
\text { Section }\end{array}$ & Age & Chondrites & Planolites & Zoophycos \\
\hline Site 378 & & & & \\
& & & & \\
$6-2$ & Upper Pliocene & & & $\mathrm{X}$ \\
$6-8$ & Upper Pliocene & $\mathrm{X}$ & $\mathrm{X}$ & $\mathrm{X}$ \\
$7-1$ & Upper Pliocene & $\mathrm{X}$ & $\mathrm{X}$ & $\mathrm{X}$ \\
$7-2$ & Upper Pliocene & $\mathrm{X}$ & & $\mathrm{X}$ \\
$7-4$ & Upper Pliocene & $\mathrm{X}$ & & $\mathrm{X}$ \\
$8-2$ & Upper Pliocene & $\mathrm{X}$ & $\mathrm{X}$ & \\
$11-2$ & Lower Pliocene & $\mathrm{X}$ & $\mathrm{X}$ & \\
$11-4$ & Lower Pliocene & & & \\
\hline
\end{tabular}

drilled on Leg 42A, only those structures produced last or deepest in the sediment by burrowing organisms are preserved in the geologic record (Ekdale, 1974).

In addition to evidence from plankton, benthic micro-organisms, and sediment attributes (other papers, this volume), the paleobathymetric interpretation of trace fossil occurrences in Leg $42 \mathrm{~A}$ cores may be an important aid to understanding the depth and configuration of the Mediterranean sea floor prior to the advent of the Messinian salinity crisis. The characteristic deep-sea trace fossil assemblage of Chondrites, Planolites, and Zoophycos is abundant in lower Miocene to upper Miocene (Tortonian) pelagic sediment from Sites 372 (Menorca Rise in the Belearic Basin) and 375 (Florence Rise in the Levantine Basin). This suggests that water depths of hundreds or thousands of meters existed in these two basins throughout the Miocene prior to the period of massive evaporite deposition.

The same trace fossil assemblage (Chondrites, Planolites, and Zoophycos) occurs in Pliocene to Pleistocene pelagic sediment from Sites 371, 373A, 374, 376, and 378. Present water depths at these five sites range from 1835 to 4078 meters, and the trace fossils indicate that similar depths must have existed there throughout post-Messinian time.

\section{ACKNOWLEDGMENTS}

This research was funded by the University of Utah Research Committee. I also would like to acknowledge the assistance and friendly encouragement of R.E. Garrison, K.J. Hsü, and the DSDP curatorial staff. R.B. Kidd, J.E. Warme, and $\mathrm{R}$. Wright read the manuscript and offered valuable suggestions for its improvement.

\section{REFERENCES}

Alpert, S. P., 1975. Planolites and Skolithos from the Upper Precambrian-Lower Cambrian, White-Inyo Mountains, California: J. Paleontol., v. 49, p. 508-521.

Arrhenius, G. 1952. Sediment cores from the East Pacific: Rept. Swedish Deep-Sea Exped., 1947-48., v. 5, p. 1-227.

Bourne, D. W. and Heezen, B. C., 1965. A wandering enteropneust from the abyssal Pacific and the distribution of "spiral" tracks on the sea floor: Science, v. 150, p. 60 63.

Bramlette, M. N. and Bradley, W. H., 1940. Geology and biology of North Atlantic deep-sea cores: U.S. Geol. Survey Prof. Paper 196, 155 p.
Chamberlain, C. K., 1971. Bathymetry and paleoecology of Ouachita geosyncline of southeastern Oklahoma as determined from trace fossils: Am. Assoc. Petrol. Geol. Bull., v. 55 , p. $34-50$.

1975. Trace fossils in DSDP cores of the Pacific. J. Paleontol., v. 49, p. 1074-1096.

Chamberlain, C. K. and Clark, D. L., 1973. Trace fossils and conodonts as evidence for deep-water deposits in the Oquirrh Basin of Central Utah: J. Paleontol., v. 47, p. 663682.

Crimes, T. P., 1975. Colonisation of the early ocean floor: Nature, v. 248 , p. $328-330$.

Donahue, J., 1971. Burrow morphologies in north-central Pacific sediments: Marine Geol., v. Il, p. 1-7.

Ekdale, A. A., 1974. Geologic history of the abyssal benthos: Evidence from trace fossils in Deep Sea Drilling Project cores: Ph.D. Dissertation, Rice University, Houston.

Ericson, D. B., Ewing, M. E., Wollin, G., and Heezen, B. C., 1961. Atlantic deep-sea sediment cores: Geol. Soc. Am. Bull., v. 72, p. 193-286.

Ewing, M. E. and Davis, R. A., 1967. Lebensspuren photographed on the ocean floor. In Hersey, J. B. (Ed.), Deepsea photography: Baltimore (Johns Hopkins), p. 259-294.

Frey, R. W., 1970. Trace fossils of Fort Hayes Member of Niobrara Chalk (Upper Cretaceous), West-central Kansas. Paleontol. Contrib. Univ. Kansas, Art. 53, 41 p. 1972. Paleocology and depositional environment of Fort Hays Limestone Member, Niobrara Chalk (Upper Cretaceous), west-central Kansas: Paleontol. Contrib. Univ. Kansas, Art. 58, 72 p.

Häntzschel. W., 1962. Trace fossils and problematica. In Moore, R. C.(Ed.), Treatise on invertebrate Paleontology. Part W., Miscellanea. Lawrence, Kansas (Univ. Kansas and Geol. Soc. Am.), p. 177-245. 1965. Vestigia invertebratorum et problematica. In Westphal, F. (Ed.), Fossilium Catalogus. I. Animalia: Gravenhage (Uitgeverij Dr.), p. 1-142. 1975. Trace fossils and problematica, second edition, In Teichert, C. (Ed.), Treatise on Invertebrate Paleontology. Part W. Supp. 1, Miscellanea: Lawrence, Kansas (Univ. Kansas and Geol. Soc. Am.), p. 1-269.

Heezen, B. C. and Hollister, C. D., 1971. The face of the deep: New York (Oxford Univ.).

Hollister, C. D., Heezen, B. C., and Nafe, K. E., 1975. Animal Traces on the deep-sea floor. In Frey, R. W. (Ed.), The study of trace fossils: New York (SpringerVerlag).

Kennedy, W. J., 1975. Trace fossils in carbonate rocks. In Frey, R. W. (Ed.), The study of trace fossils: New York (Springer-Verlag).

Kern, J. P. and Warme, J. E., 1974. Trace fossils and bathymetry of the Upper Cretaceous Point Loma Formation, San Diego, California: Geol. Soc. Am. Bull. v. 85, p. 893-900.

Lewis, D. W., 1970. The New Zealand Zoophycos: New Zealand J. Geol. Geophys; v. 13, p. 295-315.

Menzies, R. J., George, R. Y., and Rowe, R. T., 1973. Abyssal environment and ecology of the world ocean: New York (John Wiley).

Osgood, R. G., Jr., 1970. Trace fossils of the Cincinnati area: Palaeontograph. Am., v. 6 p. 281-444.

Osggod, R. G., Jr., and Szumuc, E. J., 1972. The trace fossil Zoophycos as an indicator of water depth: Am. Paleontol. Bull., v. 62 , p. 1-22.

Piper, D. J. W. and Schrader, H. J., 1973. Bioturbation of sediments. In Kulm, L. D. and von Huene, R., et al., Initial Reports of the Deep Sea Drilling Project, Volume 
18: Washington (U.S. Government Printing Office), p. 869-876.

Rodriquez, J. and Gutschick, R. C., 1970. Late Devonianearly Mississippian ichnofossils from western Montana and northern Utah. In Crimes, T. P. and Harper, J. C. (Eds.), Trace fossils: Liverpool (Seel House), p. 407-438.

Ryan, W. B. F. and Hsü, K. J., 1973. Initial Rpts. Deep Sea Drilling Project, Volume 13: Washington (U.S. Government Printing Office).

Sanders, H. L. and Hessler, R. R., 1969. Ecology of the deepsea benthos: Science, v. 163, p. 1419-1424.

Seilacher, A., 1963. Kaledonischer Unterban der Irakiden: Neues Jahrb. Geol. Palaeontol., v. 10, p. 527-542.

1964. Biogenic sedimentary structures. In Imbrie, J. and Newell, N. D. (Eds.), Approaches to paleoecology: New York (John Wiley), p. 296-316.

1967. Bathymetry of trace fossils: Marine Geol., v. 5, p. 413-428.

Simpson, S., 1957. On the trace fossil Chondrites: Quart. J. Geol. Soc. London, v. 112, p. 475-499.
1970. Notes on Zoophycos and Spirophyton. In Crimes, T. P. and Harper, J. C. (Eds.), Trace fossils: Liverpool (Seel House), p. 505-514.

Taylor, B. J., 1967. Trace fossils from the Fossil Bluff Series of Alexander Island: British Antarctic Survey Bull., v. 13, p. 1-30.

van der Lingen, G. J., 1973. Ichnofossils in deep-sea cores from the southwest Pacific. In Burns R. E., Andrews, J. E., et al., Initial Reports of the Deep Sea Drilling Project, Volume 21: Washington (U.S. Government Printing Office), p. 693-700.

Warme, J. E., Kennedy, W. J., and Schneidermann, N., 1973. Biogenic sedimentary structures (trace fossils) in Leg 15 cores. In Edgar, N. T., Saunders, J. B. et al., Initial Reports Deep Sea Drilling Project, Volume 15: Washington (U.S. Government Printing Office), p. 813-831.

Zenkevitch, L. A. (Ed.), 1970. The Pacific Ocean-biology of the Pacific Ocean. Part II, The deep-sea bottom fauna. Pleuston: Washington (U.S. Naval Oceanograph. Office, Trans. 487), p. 421. 


\section{PLATE 1}
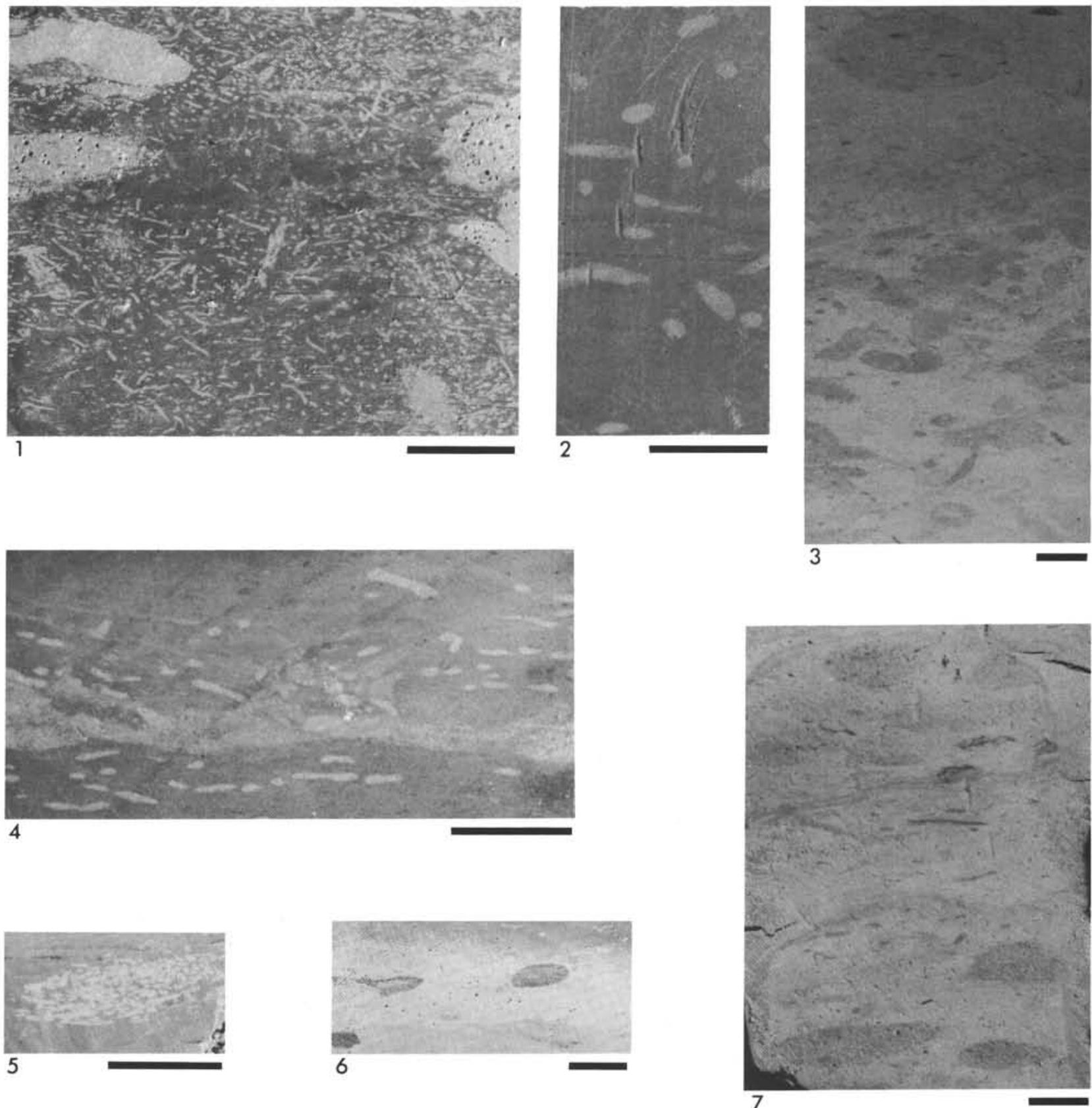

Trace Fossils (bar equals $1 \mathrm{~cm}$ ).

Figure 1 Chondrites, Sample 375-8-1, 91-96 cm.

Figure 2 Chondrites, Sample 373A-2-1, 109-113 cm.

Figure 3 Planolites, Sample 372-28-6, 88-106 cm.

Figure 4 Chondrites, Sample 375-8-3, 110-112 cm.

Figure $5 \quad$ Chondrites, Sample 275-8-5, 67-68 cm.

Figure 6 Planolites, Sample 375-8-0, 16-17 cm.

Figure 7 Planolites, Sample $372-27-5,32-40 \mathrm{~cm}$. 


\section{PLATE 2}
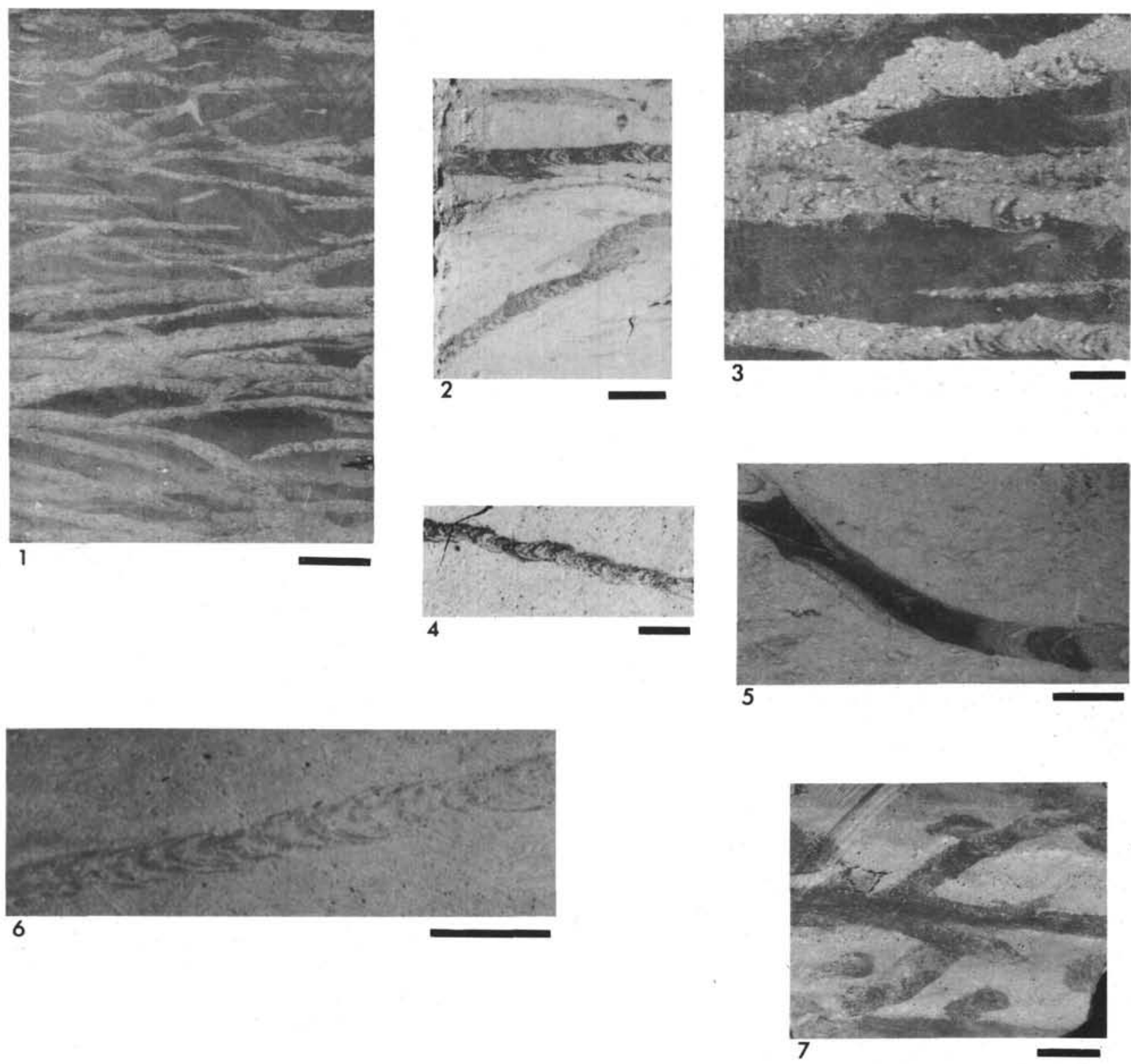

Trace Fossils (bar equals $1 \mathrm{~cm}$ ).

Figure 1 Zoophycos, Sample 375-9-2, 22-30 cm.

Figure 2 Zoophycos, Sample 374-9-3, 74-79 cm.

Figure 3 Zoophycos, Sample 375-9-4, $37-41 \mathrm{~cm}$.

Figure 4 Zoophycos, Sample 374-5-2, 124-126 cm.

Figure 5 Zoophycos, Sample 372-31-5, 106-109 cm.

Figure 6 Zoophycos, Sample 372-32-1, 29-31 cm.

Figure 7 Zoophycos, Sample 375-8-0, 8-12 cm. 